\title{
Protective effect of policosanol on atherosclerotic lesions in rabbits with exogenous hypercholesterolemia
}

M.L. Arruzazabala,

M. Noa, R. Menéndez, R. Más, D. Carbajal,

S. Valdés and V. Molina
Department of Pharmacology, Center of $\mathrm{N}$ atural Products, National Center of Scientific Research, Havana, Cuba

\section{Correspondence \\ M. Noa \\ Laboratory of Histology \\ Department of Pharmacology \\ Center of $\mathrm{N}$ atural Products \\ National Center for Scientific Research \\ 25 Ave and 158 Street \\ Post O ffice Box 6990 \\ Havana \\ Cuba \\ Fax: + 53-7-336-837/330-497}

Received July 22, 1999

Accepted February 29, 2000

\begin{abstract}
Policosanol is a mixture of higher aliphatic alcohols purified from sugar cane wax, with cholesterol-lowering effects demonstrable in experimental models and in patients with type II hypercholesterolemia. The protective effects of policosanol on atherosclerotic lesions experimentally induced by lipofundin in rabbits and rats and spontaneously developed in stumptail monkeys have been described. The present study was conducted to determine whether policosanol administered orally to rabbits with exogenous hypercholesterolemia also protects against the development of atherosclerotic lesions. Male New Zealand rabbits weighing 1.5 to $2 \mathrm{~kg}$ were randomly divided into three experimental groups which received 25 or $200 \mathrm{mg} / \mathrm{kg}$ policosanol ( $\mathrm{N}$ $=7$ ) orally for 60 days with acacia gum as vehicle or acacia gum alone (control group, $\mathrm{N}=9$ ). All animals received a cholesterol-rich diet $(0.5 \%)$ during the entire period. Control animals developed marked hypercholesterolemia, macroscopic lesions and arterial intimal thickening. Intima thickness was significantly less $(32.5 \pm 7$ and $25.4 \pm 4)$ in hypercholesterolemic rabbits treated with policosanol than in controls $(57.6 \pm 9)$. In most policosanol-treated animals, atherosclerotic lesions were not present, and in others, thickness of fatty streaks had less foam cell layers than in controls. We conclude that policosanol has a protective effect on the atherosclerotic lesions occurring in this experimental model.
\end{abstract}

\section{Introduction}

Policosanol is a natural mixture of higher aliphatic primary alcohols purified from sugar cane (Saccharum officinarum, L.) wax. It consists of $66 \%$ octacosanol (molecular mass of 410.7 ), $12 \%$ triacontanol (molecular mass of 438.5), $7 \%$ hexacosanol (molecular mass of 382.4 ) and $15 \%$ other alcohols (tetracosanol, heptacosanol, nonacosanol, dotriacon-

\section{Key words}

- Policosanol

- Atherosclerotic lesions

- Exogenous

hypercholesterolemia

- Rabbits tanol and tetratriacontanol). Policosanol reduces total cholesterol and low density lipoprotein (LDL) cholesterol levels in different experimental models (1-3), in healthy volunteers (4) and in patients with type II hypercholesterolemia (5-13).

Policosanol acts by inhibiting cholesterol biosynthesis at a step before mevalonate production and by increasing the receptor-dependent LDL processing (14-16). 
The cholesterol-lowering effect of policosanol has also been demonstrated in rabbits fed a fat-free and casein-rich diet, an experimental model in which cholesterol biosynthesis is enhanced and the number of LDL receptors is reduced, and for this reason it has been considered a model of endogenous hypercholesterolemia. This model has been useful to evaluate the cholesterol-lowering effectiveness of cholesterol biosynthesis inhibitors such as statins $(17,18)$.

On the other hand, previous experiments have revealed that policosanol prevents the development of spontaneous lesions in Macaca arctoides monkeys (19) and in lesions induced by lipofundin in rabbits and rats (20-22). To date, the effect of policosanol on the atherosclerotic lesions induced in rabbits by a cholesterol-rich diet has not been evaluated. In fact, this model is not suitable to evaluate the efficacy of cholesterol-lowering drugs acting by the inhibition of cholesterol biosynthesis $(23,24)$, since this process is naturally depressed by a feedback control. The present study was undertaken to determine the effects of policosanol on the development of atherosclerotic lesions in rabbits rendered hypercholesterolemic by a cholesterol-rich diet.

\section{Material and Methods}

\section{Animals}

Twenty-three male New Zealand rabbits weighing 1.5 to $2 \mathrm{~kg}$ were obtained from the National Center for Laboratory Animal Production (CENPALAB, Santiago de las Vegas, Havana, Cuba). These animals were adapted to experimental conditions for 15 days and divided into groups at random. Normal rabbit chow and water were supplied ad libitum.

From this moment $(t=0)$ until the end of the experiment, animals were fed a cholesterol-rich chow obtained from CENPALAB. Consumption was adjusted to $100 \mathrm{~g} \mathrm{rabbit}^{-1}$ day $^{-1}$. The composition of the chow was as follows: raw fat $(3.47 \%)$, cholesterol $(0.5 \%)$, raw fiber $(14.51 \%)$, raw protein $(16.68 \%)$, total carbohydrates $(60.22 \%)$, phosphorus $(0.53 \%)$, humidity (12.0\%), and $\mathrm{pH} 5.31$. Food intake of all animals was always the same.

\section{Administration and dosage}

Policosanol (batch L-C-11), obtained from the National Center for Scientific Research (Havana, Cuba) was used as a suspension in acacia gum $/$ water $(10 \mathrm{mg} / \mathrm{ml})$ after quality control by gas chromatography. All treatments were administered orally by gavage $(1 \mathrm{ml} / \mathrm{kg}$ ) for 60 days. Starting on day 0 , the experimental groups were: 1 ) controls (animals receiving only the vehicle), 2) 25 $\mathrm{mg} / \mathrm{kg}$ policosanol, and 3) $200 \mathrm{mg} / \mathrm{kg}$ policosanol. Simultaneously, the animals received the cholesterol-rich diet $(0.5 \%)$ described above. The doses used were based on previous data obtained for normocholesterolemic rabbits (2).

\section{Experimental procedure}

To determine serum cholesterol levels, blood samples were drawn by puncturing the ear marginal vein before $(t=0)$ and 30 and 60 days after treatment. Blood sampling was performed after a 12-h fast. Levels were measured enzymatically using BoehringerMannheim (Mannheim, Germany) total cholesterol reagents.

At the end of the experiment, animals were anesthetized with ether and sacrificed after a 12-h overnight fast.

\section{Morphological study}

Aortas were removed and opened lengthwise from the aortic vessel up to the left renal artery. After observation, lesions were classified according to a 0 - to 4-intensity scale: $0=$ no lesion, $1=$ few fatty streaks, $2=$ 
many fatty streaks, $3=$ large quantities of fatty streaks, and $4=$ fibrous plaque. The aortas were then immediately fixed in $10 \%$ buffered formaldehyde and processed for light microscopy.

Maximum thickening of the intima was measured for each animal (25) using an ocular grid and an Olympus micrometric slide, with the same magnification of $100 \mathrm{X}$. Thickening of the intima was always measured from the elastica and is reported as mm. Five arterial segments per animal were evaluated.

\section{Statistical analysis}

The Kruskal-Wallis test was applied to determine differences among all groups. Control and treated groups were compared by the Mann-Whitney U-test. To compare variations in relation to baseline the Wilcoxon test was used.

\section{Results}

\section{Effect of policosanol on serum cholesterol levels}

Policosanol administered orally at 25 and $200 \mathrm{mg} / \mathrm{kg}$ did not significantly inhibit the increase in serum cholesterol levels induced by the cholesterol-rich diet (Table 1).

\section{Effect of policosanol on aortic atherosclerotic lesions in rabbits}

Macroscopic observations of rabbit aor- tas showed fatty streaks with defined margins along the dorsal surface. A significant and dose-dependent reduction of the mean score of the lesions was observed in policosanol-treated animals compared with controls (Table 2).

After microscopic analysis of hematoxylin and eosin-stained sections, these lesions were classified as fatty streaks, with many foam cells of macrophage or myogenic origin. Comparisons between groups concerning intima thickening also showed significantly lower values in treated groups than in the controls (Table 2; Figure 1A-C).

\section{Discussion}

This study demonstrates that policosanol (25 and $200 \mathrm{mg} / \mathrm{kg}$ ) administered orally to rabbits fed a cholesterol-rich diet was effective in preventing the development of atherosclerotic lesions in the aorta, but not in inhibiting the increase in serum cholesterol levels induced by this diet.

Policosanol acts by inhibiting cholesterol biosynthesis at a step between acetate consumption and mevalonate production (14).

Policosanol $(5-200 \mathrm{mg} / \mathrm{kg})$ is effective in reducing cholesterol levels in normocholesterolemic rabbits (2) and $25 \mathrm{mg} / \mathrm{kg}$, the low dose tested, was able to prevent the increase in cholesterol and LDL levels in rabbits fed a fat-free casein-rich diet (a model of endogenous hypercholesterolemia) (15).

The present results are consistent with the mode of action of the drug as well as the

Table 1 - Lack of effect of policosanol on serum cholesterol levels of rabbits fed a cholesterol-rich diet.

Data are reported as means \pm SD for serum cholesterol $(\mathrm{mM})$ for 7 to 9 rabbits per group. Treatment and diet started on day $0 . \Delta_{1}$, Increase after 30 days; $\Delta_{2}$, increase after 60 days. ${ }^{*} P<0.05$ compared to day 0 (Wilcoxon test).

\begin{tabular}{lcccccc}
\hline Groups & Dose $(\mathrm{mg} / \mathrm{kg})$ & Day 0 & Day 30 & $\Delta_{1}$ & Day 60 & $\Delta_{2}$ \\
\hline Control $(\mathrm{N}=9)$ & 0 & $1.32 \pm 0.55$ & $19.87 \pm 4.80^{*}$ & 18.6 & $22.58 \pm 5.70^{*}$ & 21.3 \\
Policosanol $(\mathrm{N}=7)$ & 25 & $1.33 \pm 0.50$ & $19.27 \pm 6.80 *$ & 18.4 & $20.63 \pm 7.90^{*}$ & 19.0 \\
Policosanol $(\mathrm{N}=7)$ & 200 & $1.30 \pm 0.40$ & $17.60 \pm 7.70^{*}$ & 16.2 & $20.14 \pm 8.80^{*}$ & 17.9
\end{tabular}


characteristic of each model. Thus, the hypercholesterolemia induced by a fat-free, casein-starch diet is related to an increase in cholesterol biosynthesis and a reduction in the number of hepatic LDL receptors $(17,18)$. As a consequence, drugs acting on such events must be effective in this model.

In the model of exogenous hypercholesterolemia, the synthesis of cholesterol is inhibited as a result of the feedback mechanism generated because the high intracellular concentration of these metabolites inhibits Apo B receptor synthesis, limiting LDL uptake from plasma $(23,24)$. So, cholesterol synthesis is already inhibited and this is one of the reasons why the cholesterol-lowering effect of drugs that act by inhibiting cholesterol biosynthesis is not easily apparent in this model. Lovastatin lowers plasma cholesterol levels in cholesterol-fed rabbits with exogenous hypercholesterolemia $(26,27)$, but this effect is associated with a decreased intestinal absorption of cholesterol (28). Other authors have also suggested that the HMG-CoA reductase inhibitors simvastatin and lovastatin reduce cholesterol absorption both in rabbits and in man (29).

Previous studies have demonstrated that policosanol prevents the onset of spontaneous atherosclerotic lesions in Macaca arctoides monkeys (19) and in lipofundininduced lesions in rabbits and rats (20-22). The physiological basis of this action may be related not only to the cholesterol-lowering

Table 2 - Effect of policosanol on macroscopic lesions and intimal thickening in aortas from hypercholesterolemic rabbits.

Thickness is reported as means \pm SD. Lesion score 0 : no lesion, 1 : few fatty streaks, 2: many fatty streaks, 3: large quantities of fatty streaks, and 4: fibrous plaque. $* \mathrm{P}<0.05, * * \mathrm{P}<0.01$ (Kruskal-Wallis test), compared to control group (Mann-Whitney U-test).

\begin{tabular}{lccc}
\hline Groups & $\begin{array}{c}\text { Dose } \\
(\mathrm{mg} / \mathrm{kg})\end{array}$ & \multicolumn{1}{c}{$\begin{array}{c}\text { Lesion } \\
\text { score }\end{array}$} & $\begin{array}{c}\text { Intima thickness } \\
(\mu \mathrm{m})\end{array}$ \\
\hline Control $(\mathrm{N}=9)$ & 0 & $2.50 \pm 0.75$ & $57.6 \pm 9.62$ \\
Policosanol $(\mathrm{N}=7)$ & 25 & $1.44 \pm 0.88^{*}$ & $32.5 \pm 7.07^{* *}$ \\
Policosanol $(\mathrm{N}=7)$ & 200 & $0.56 \pm 0.41^{* *}$ & $25.4 \pm 4.80^{* *}$
\end{tabular}
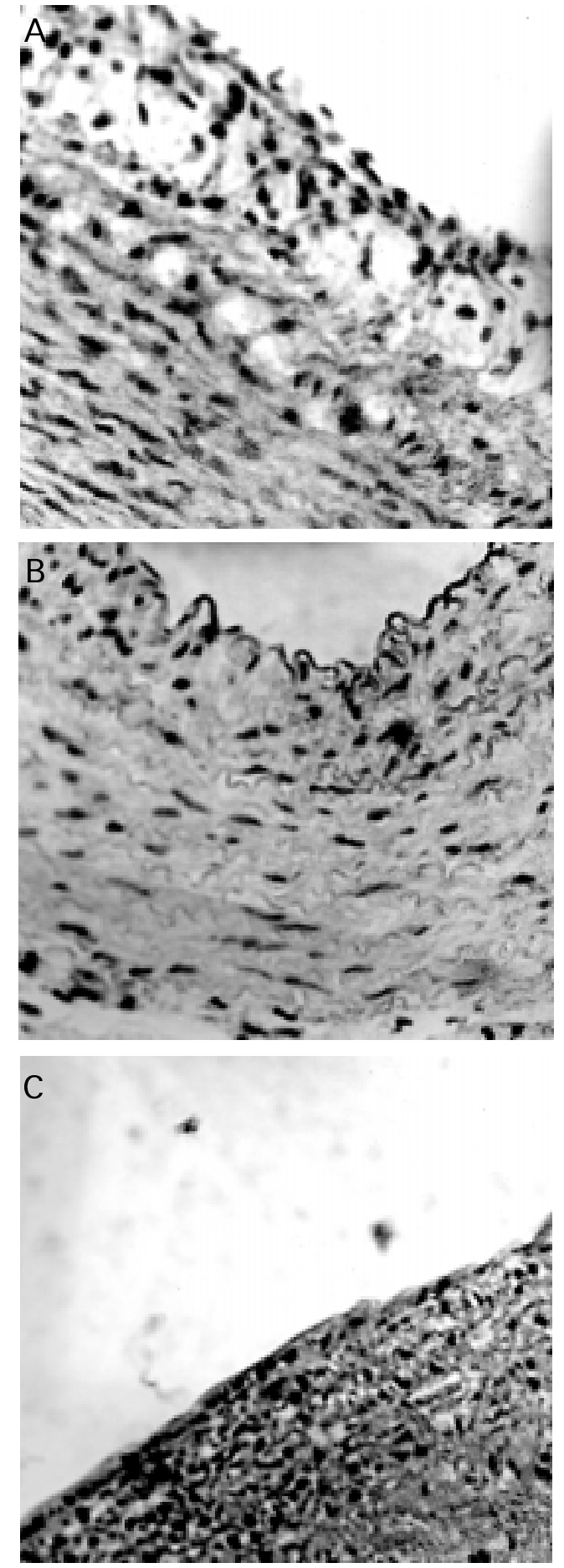

Figure 1 - Photomicrographs showing the general histologic appearance of thoracic aortas in cholesterol-fed rabbits. A, Cross-section of the thoracic aorta from a control group. Lesion was evaluated as fatty streaks. Note thickening of the intima with layers of foam cells. $\mathrm{B}$ and $\mathrm{C}$, Intact arterial walls are observed in policosanol-treated rabbits ( 25 and $200 \mathrm{mg} / \mathrm{kg}$, respectively). Hematoxylin-eosin, 225X. 
effects of policosanol, but also to the reduction of thromboxane $\mathrm{A}_{2}\left(\mathrm{TxA}_{2}\right)$ and to the increase in prostacyclin levels induced by policosanol (30). Skrinska et al. (31) showed that rabbits fed a hypercholesterolemic diet and treated with a thromboxane synthetase inhibitor(UK-38485) developed significantly fewer lesions due to foam cells than those fed the atherogenic diet only. It has been also reported that $\mathrm{BM} 13505$, a specific $\mathrm{TxA}_{2}$ antagonist, has an antiatherogenic effect by reducing the deposition of cholesterol on the arterial wall and by retarding plaque formation in coronary arteries of cholesterol-fed rabbits (32).

On the other hand, prostacyclin reduces atherogenic cholesteryl ester accumulation in macrophages and vessel wall (33), inhibits platelet activation and mitogen release (34) and shows antiproliferative effects on vascular smooth muscle cells (35). These cells, like macrophages, develop in foam cells which are the principal cells present in the fatty streak.

In addition, Jellinek et al. (36), using the lipofundin-induced atherosclerotic lesion model, showed a beneficial effect of iloprost (prostacyclin) and Braun et al. (37) described a significant reduction of atherosclerotic lesions in aortas from rabbits fed a cholesterolenriched diet and treated with cicaprost (an oral prostacyclin mimetic), but no changes in cholesterol levels. All of these actions suggest that prostacyclin is an agent protecting against atherosclerosis.

The above data suggest that the effects of policosanol on $\mathrm{TxA}_{2}$ and prostacyclin could be the reason why policosanol prevents atherosclerotic lesions in rabbits fed a cholesterol-enriched diet.

Bocan et al. (38) evaluated the antiatherosclerotic and lipid-lowering activity of some HMG-CoA reductase inhibitors (simvastatin, lovastatin, PD134965) in cholesterol-fed rabbits and demonstrated that lesion size was unchanged in these animals. Nevertheless, they showed that atorvastatin reduced the size of arterial lesions and concluded that the antiatherosclerotic potential of these drugs is compound specific and clearly not a class effect.

The doses used in this experiment had no toxic effects on the experimental animals $(39,40)$.

The present results agree with previous works showing the preventive effects of policosanol on the development of atherosclerotic lesions and demonstrate that the antiatherosclerotic effects of policosanol in this experimental model are not related to its cholesterol-lowering effects.

\section{References}

1. Arruzazabala $M L$, Carbajal D, Más R, Castaño G, Sotolongo R \& Mesa R (1991). Efecto del ateromixol (PPG) sobre los niveles de colesterol en perros Beagle. Revista del Centro Nacional de Investigaciones Científicas de Ciencias Biológicas, 22: 60-61.

2. Arruzazabala $M L$, Carbajal $D, M a ́ s ~ R$, Molina V, Valdés S \& Laguna A (1994). Cholesterol-lowering effects of policosanol in rabbits. Biological Research, 27: 205-208.

3. Rodríguez C, Mesa R, Más R, Amor AM \& Castaño G (1992). Estudio del efecto sobre los lípidos y lipoproteinas séricos y de la tolerancia al tratamiento oral con dosis crecientes de Ateromixol (PPG) en monos Macaca arctoides. Archivos Venezolanos de Farmacología y Terapeútica, 11: 74-79.

4. Hernández F, Illnait J , Más R, Castaño G, Fernández L, González M, Cordoví N \& Fernández J C (1992). Effects of policosanol on serum lipids and lipoproteins in healthy volunteers. Current Therapeutic Research, 51: 568-575.

5. Castaño G, Zardoya R, Illnait J, Más R, Fernández L, Surribas $E$, Nodarse $M$ \& Fernández J C (1991). Efectos del tratamiento con Ateromixol (PPG) $(5 \mathrm{mg}$ ) en pacientes con hiperlipoproteinemia tipo II. Progresos en Ciencias Médicas, 5: 21-
28.

6. Pons $P$, Más R, Illnait J, Fernández L, Rodríguez $M$, Robaina $C \&$ Fernández J $C$ (1992). Efficacy and safety of policosanol in patients with primary hypercholesterolemia. Current Therapeutic Research, 52: 507-513.

7. Pons $P$, J iménez $A$, Rodríguez $M$, Illnait J, Más R, Fernández L \& Fernández JC (1993). Effects of policosanol on elderly hypercholesterolemic patients. Current Therapeutic Research, 53: 265-269.

8. Pons $P$, Rodríguez M, Robaina C, Illnait J , Más R, Fernández $L$ \& Fernández JC (1994). Effects of policosanol successive dose increases on lipid profile of patients 
with type II hypercholesterolemia and tolerability to treatment. J oumal of Clinical Pharmacological Research, XIV: 27-33.

9. Pons $P$, Rodríguez $M$, Más $R$, Illnait J, Fernández L, Robaina $C \&$ Fernández J C (1994). One year efficacy and safety of policosanol in patients with type II hypercholesterolemia. Current Therapeutic Research, 55: 1084-1092.

10. Aneiros $E$, Calderón B, Más R, Illnait J, Castaño G, Fernández L \& Fernández J C (1993). Effects of successive dose increases of policosanol on the lipid profile and tolerability of treatment. Current Therapeutic Research, 54: 304-312.

11. Aneiros E, Más R, Calderón B, Illnait J, Fernández L, Castaño G \& Fernández J C (1995). Policosanol for cholesterol-lowering levels in patients with type II hypercholesterolemia. Current Therapeutic Research, 56: 176-182.

12. Soltero I, Fuenmayor I \& Colmenares J (1993). Estudio comparativo doble ciego de la eficacia y tolerancia del policosanol vs bezafibrato en pacientes con hiperlipidemias tipo II. Archivos Venezolanos de Farmacología y Terapeútica, 12: 71-76.

13. Zardoya R, Tula L, Castaño G, Más R, Illnait J , Fernández J C, Díaz E \& Femández L (1996). Effects of policosanol on hypercholesterolemic patients with disturbances on serum biochemical indicators of hepatic function. Current Therapeutic Research, 57: 568-577.

14. Menéndez R, Fernández I, Del Río $A$, González RM, Fraga V, Amor AM, J iménez S \& Más R (1994). Policosanol inhibits cholesterol biosynthesis and enhances LDL processing in cultured human fibroblasts. Biological Research, 27: 199-203.

15. Menéndez $R$, Arruzazabala $M L$, Más $R$, del Río A, Amor AM, González RM, Carbajal D, Fraga V, Molina V \& IIInait J (1997). Cholesterol-lowering effect of policosanol on rabbits with hypercholesterolemia induced by a wheat starch-casein diet. British J ournal of Nutrition, 77: 923932.

16. Menéndez R, Fraga V, Sotolongo V, Amor $A M$, del Rio A, González RM, J iménez $S$ \& Más R (1993). Efecto de la administración oral del policosanol sobre el metabolismo lipídico de ratas normocolesterolémicas. Revista Mexicana de Ciencias Farmaceúticas, 24: 16-18.

17. Kroon PA, Hand KM, Huff J W \& Alberts AW (1982). The effects of mevinolin on serum cholesterol levels of rabbits with endogenous hypercholesterolemia. Atherosclerosis, 44: 41-48.
18. Chao YS, Kroon PA, Yamin TT, Thomson GM \& Alberts AW (1983). Regulation of hepatic receptor-dependent degradation of LDL by mevinolin in rabbits with hypercholesterolemia induced by a wheat starch-casein diet. Biochimica et Biophysica Acta, 754: 134-141.

19. Rodríguez $C$, Mesa $R$, Más $R$, Noa $M$, Menéndez R, González RM, Amor AM, Fraga V, Sotolongo V \& Laguna A (1994). Study of policosanol oral chronic toxicity in male monkeys (Macaca arctoides). Food and Chemical Toxicology, 32: 565575.

20. Noa M \& Más R (1992). Ateromixol y lesión aterosclerótica en conejos inducida por lipofundin. Progresos en Ciencias Médicas, 6: 14-19.

21. Noa M, Más R, de la Rosa MC \& Magraner J (1995). Effect of policosanol on lipofundin-induced atherosclerotic lesions in rats. J ournal of Pharmacy and Pharmacology, 47: 289-291.

22. Noa M, Más R \& de la Rosa MC (1996). Effect of policosanol on foam cell formation in carrageenan-induced granulomas in rats. J ournal of Pharmacy and Pharmacology, 48: 306-309.

23. Brown MS \& Goldstein J L (1976). Receptor mediated control of cholesterol metabolism. Science, 191: 150-152.

24. Andersen J M, Turkey SD \& Dietchy J M (1982). Relative rates of sterol synthesis in the liver and various extrahepatic tissues of normal and cholesterol-fed rabbits. Relationship to plasma lipoprotein and tissue cholesterol levels. Biochimica et Biophysica Acta, 711: 421-430.

25. Atkinson $D$, Hoover R, Berry $K \&$ Swilt $L$ (1989). Cholesterol-fed heterozygous Watanabe heritable hyperlipidemic rabbits: a new model for atherosclerosis. Atherosclerosis, 79: 123-136.

26. Kritchevsky $D$, Tepper $A \&$ Klurfeld $D$ (1981). Influence of mevilonin on experimental atherosclerosis in rabbits. Pharmacological Research Communications, 13: 921-926.

27. Kobayashi $M$, Ishida $F$, Takahashi $T \&$ Taguchi K (1989). Preventive effect of MK733 (simvastatin), an inhibitor of HMGCoA reductase, on hypercholesterolemia and atherosclerosis induced by cholesterol feeding in rabbits. J apanese J ournal of Pharmacology, 49: 125-133.

28. Nielsen LB, Stender $S \&$ Kjeldsen $K$ (1993). Effect of lovastatin on cholesterol absorption in cholesterol-fed rabbits. Pharmacology and Toxicology, 72: 148-151.

29. Ishida $F$, Sako A, lizuka $Y$, Sawasaki $Y$, Aizaswa A \& Kamei T (1988). Effects of
MK-733, an inhibitor of 3-hydroxy-3methylglutaryl-coenzyme $A$ reductase, on absorption and excretion of $(\mathrm{H})$ cholesterol in rabbits. Biochimica et Biophysica Acta, 963: 35-41.

30. Arruzazabala $M L$, Carbajal D, Más $R$, García M \& Fraga V (1993). Effects of Ateromixol on platelet aggregation in rats. Thrombosis Research, 69: 321-327.

31. Skrinska V, Konieczkowski M, Gerrity R, Galang C \& Rebec M (1988). Suppression of foam cell lesions in hypercholesterolemic rabbits by inhibition of thromboxane A synthesis. Atherosclerosis, 8: 359-367.

32. Osborne J \& Leffer A (1988). Cardioprotective actions of thromboxane receptor antagonism in ischemic atherosclerotic rabbits. American J oumal of Physiology, 255 (Heart and Circulatory Physiology, 24): $\mathrm{H}-318-\mathrm{H}-324$.

33. Hajjar DP \& Pomerantz KB (1989). Eicosanoids and their role in atherosclerosis. Archives des Maladies du Coeur et des Vaisseaux, 82: 21-23.

34. Willis AL \& Smith DL (1989). Therapeutic impact of eicosanoids in atherosclerotic disease. Eicosanoids, 2: 69-71.

35. Fredrich $M \&$ \& Muller B (1992). Prostacyclin and atherosclerosis. In: Rubanyi GM \& Vane J (Editors), Prostacyclin: New Perspectives for Basic Research and Novel Therapeutic Indications. Elsevier, Amsterdam, 169.

36. J ellinek H, Stock G \& Takacsm E (1987). Lipofundin arteriosclerosis and iloprost treatment. In: Gryglewski R \& Stock G (Editors), Prostacyclin and Its Stable Analogue lloprost. Springer, Heidelberg, 269.

37. Braun $M$, Hohlfeld Th, Kienbaum $P$, Weber A, Sarbia M \& Schror K (1994). Antiatherosclerotic effects of oral cicaprost in experimental hypercholesterolemia in rabbits. Atherosclerosis, 103: 93-105.

38. Bocan Th, Mazur M, Mueller S \& Brown E (1994). Antiatherosclerotic activity of inhibitors of 3-hydroxy-3-methylglutaryl coenzyme A reductase in cholesterol-fed rabbits: a biochemical and morphological evaluation. Atherosclerosis, 111: 127-142.

39. Alemán $C$, Más $R$, Hernández $C$, Rodeiro I, Cerejido $E$, Noa $M$ \& Menéndez R (1994). A 12 months study of policosanol oral toxicity in Sprague Dawley rats. Toxicology Letters, 70: 77-87.

40. Alemán C, Más R, Noa M, Rodeiro I, Hernández C \& Capote A (1994). Carcinogenicity of policosanol in Sprague Dawley rats. A 24 months study. Teratogenesis, Carcinogenesis, and Mutagenesis, 14: 239-249. 